\title{
CREDIT RISK EXPOSURE OF SELECTED NEW PRIVATE SECTOR BANKS IN INDIA WITH REFERENCE TO ASSET LIABILITY MANAGEMENT
}

\author{
Miss Deepa Chandwani, Dr. Gurudutta Japee
}

\author{
Ph.D. Research Scholar, \\ Gujarat University, Ahmedabad \\ deepachandwani1@gmail.com \\ Research Guide, \\ Gujarat University,Ahmedabad \\ profgurudutta@gmail.com
}

\begin{abstract}
Asset Liability management of a bank refers to strategic decision making and devising strategies with respect to mitigation of different types of risk with a core objective of risk minimization and profit maximization. Banks are exposed to varied types of risk of which credit risk is crucial as it enhances the risk of insolvency and bankruptcy of a bank. It arises when borrowers turn out to be defaulters. Credit risk not only wipes out the capital of the banks but also hampers the present and future earnings of the bank. The present paper analyzes the credit risk of selected private sector banks to know if the Asset Liability management (ALM) policy of a bank with respect to credit risk is effective or not. The different measures of Credit risk as Gross Non-performing assets and Net Nonperforming assets are analyzed using One-Way Anova to see if credit risk of selected banks is significantly different or not.
\end{abstract}

Keywords: Asset Liability management, Credit risk, Gross Non-performing assets, Net Non-performing assets and Provision Coverage ratio.

\section{INTRODUCTION}

The recent financial crisis in capital markets and the role of banks brings attention to the existing risk management systems and how they fall short in actually managing their credit risks. The ILFS, Jet Airways and DHFL defaults are just a few among the major losses caused by the failure of their lenders and counterparties in timely payment of interest and capital on their contracts. With an incessant increase in defaulters wiping out huge funds from the financial system, second recession after 2008 may be a reality waiting to happen.

But so far, the banking industry has survived because of the management of Credit risk. Credit Risk has always been a crucial area for financial institutions that also face varied risks such as operational risks, technological risks, talent risks, interest rate risk, forex risk, market risk and liquidity risk.

The research focuses on finding out the following aspects:

Is credit risk of all the banks the same?

Does ALM strategy with respect to credit risk effective in addressing credit risk issues in various banks? Is management of credit risk in banks effective or failed to address the default issues of borrowers? Credit risk not only wipes out the capital of the banks but also hampers the present and future earnings of the bank. It reduces the credit assets value with deterioration in a portfolio or individual's credit quality.

\subsection{DEFINITIONS}

Credit Risk - The Basel Committee on Banking Supervision (or BCBS) defines credit risk as "the potential that a bank borrower or counterparty will fail to meet its obligations in accordance with the agreed terms." It includes both the uncertainty involved in repayment of the bank's dues and repayment of dues on time.

According to the Basel Committee on Banking Supervision (2001), the most common cause that leads the banks to bankruptcy is credit risk. The main sources of credit risk that have been identified in the literature include limited institutional capacity, inappropriate credit policies, volatile interest rates, poor management, inappropriate laws, low capital and liquidity levels, massive licensing of banks, poor loan underwriting, reckless lending, poor credit assessment, lack of rigorousness in credit assessment, poor lending practices, government interference, inadequate supervision by the central bank and information asymmetry.

Asset Liability Management - Wikipedia defines Asset and liability management (ALM) as the practice of managing financial risks that arise due to mismatches between the assets and liabilities as part of an 


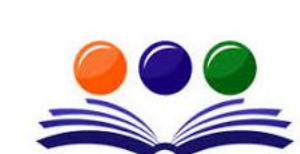

GRAND ACADEMIC PORTAL RESEARCH JOURNALS
GAP INTERDISCIPLINARITIES A Global Journal of Interdisciplinary Studies

( ISSN - 2581-5628)

Impact Factor: SJIF - 5.047, IIFS - 4.875

Globally peer-reviewed and open access journal.

investment strategy in financial accounting.

Asset Liability management refers to risk hedging mechanism of a financial institution. It is a strategic framework to achieve the organizational financial objectives, gain competitive advantage and increase the value of the organization.

\subsection{SCOPE OF ASSET LIABILITY MANAGEMENT:}

ALM focuses on analysis of comprehensive risk and different scenarios, value addition and dynamic approach of balance sheet management. The scope of ALM includes management of liquidity risk, interest rate risk, market risk, forex risk, credit risk, funding strategy, capital planning, profit planning and growth projection. ALM process involves formation of a decision-making unit named ALCO consisting of senior management i.e., CEO, CFO and other board members who decide the risk management philosophy and set the tolerance limits for varied types of risks. They analyze the current scenario of the risk and plan the future business strategy accordingly. They determine

$>$ Proper mix of assets \& liabilities based on maturity profile.

$>$ Product pricing

$>$ Funding strategy

In short, ALM encompasses analyzing risk parameters, identifying risk, measurement and management of risk, framing policies and fixing tolerance levels of varied risks.

Enhanced profits with optimum risk exposure imply that ALM policy of a bank is effective in achieving the core objectives of the bank and fulfilling the regulatory requirements.

\subsection{CAUSES OF CREDIT RISK:}

The revenue of banks comes primarily from interest on loans and accordingly loans form a major source of credit risk. Banks face credit risks from financial instruments such as acceptances, interbank transactions, trade financing, foreign exchange transactions, futures, swaps, bonds, options, settlement of transactions and others. The causes of Credit risk are:

\section{$>$ Credit Concentration}

Where the lending of the banks is majorly concentrated on specific borrower/borrowers or specific sectors or groups or industry, it causes a credit concentration.

\section{$>$ Credit Issuing Process}

This includes flaws in the banks' credit granting and monitoring processes. Although credit risk is inherent in lending, it can be kept at a minimum with sound credit practices.

The errors in the credit processes of the bank results in major credit problems include incomplete Credit Assessment and subjective decision making and inadequate monitoring.

\section{$>$ Cyclical Performances}

Almost all industries go through a depression and a boom period. During the boom period, the evaluations may result in the good creditworthiness of the borrower. However, the cyclical performance of the industry must also be taken into account in order to arrive at the results of credit evaluations more accurately.

\subsection{CREDIT RISK MANAGEMENT:}

It is the practice of mitigating losses by understanding the adequacy of a bank's capital and loan loss reserves at any given time - a process that has long been a challenge for financial institutions. The goal of credit risk management is to maximize a bank's risk-adjusted rate of return by maintaining credit risk exposure within acceptable parameters.

Banks create provisions at the time of disbursing loans. The bank should position itself to accommodate the expected outcome within profits and provisions, leaving equity capital as the final cushion for the unforeseen catastrophe.

A Credit risk Management analyst is crucial to the bank's profitability and to manage and assess credit risks, evaluate credit loan applications, ensure credit-worthiness of the borrower, monitor credit policy compliance and regulatory lending norms. A Credit risk Management analyst is a part of ALCO and plays a significant role in framing ALM strategy.

\section{LITERATURE REVIEW}

Bace (2018) presented various recommendations for effective implementations of a bank ALM process with respect to credit risk. It highlighted that credit risk exposure was the main negative impact potential on the balance sheet. ALCO must have oversight of it. This does not mean day-to-day running and minimization of credit risk origination. It means approval of policies, monitoring of exposure and approval authority on significant transactions and any policy changes.

Bharti (2018) in her essay on Treasury and Asset Liability management highlighted the types of risk in banking sector, ALM and its importance, management of interest rate risk and liquidity risk and management of credit risk through securitization and credit risk derivatives. It highlighted the new products which convert 


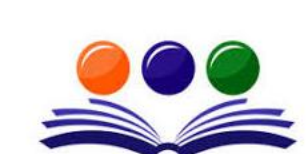

GRAND ACADEMIC PORTAL RESEARCH JOURNALS
GAP iNTERDISCIPLINARITIES A Global Journal of Interdisciplinary Studies

( ISSN - 2581-5628)

Impact Factor: SJIF - 5.047, IIFS - 4.875

Globally peer-reviewed and open access journal.

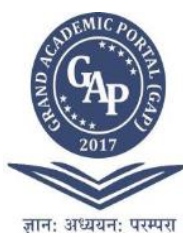

conventional credit into tradable treasury assets by the process called securitization, whereby credit receivables of the bank can be converted into units or bonds that can be traded in the market. The instruments, known as credit default swap or credit linked certificate transfer the credit risk from owner of the asset to another person who is in a position to absorb the credit risk, for a fee.

Konovalova et.al. (2016) proposed a model of credit risk assessment on the basis of factor analysis of retail clients/borrowers in order to ensure predictive control of the level of risk posed by potential clients in commercial banks engaged in consumer lending. The aim of the study was to determine the level of risk represented by different groups (classes) of retail clients (borrowers) in order to reduce and prevent credit risk in the future as well as to improve the management of banking risks. The main results of the study were the creation of a model of borrower's internal credit ratings and the development of the methods of improving credit risk management in commercial banks.

\section{RESEARCH METHODOLOGY}

\subsection{PROBLEM STATEMENT:}

The core problem of the study is:

Is the credit risk exposure of selected private sector banks the same?

Is ALM effective in management of Credit risk of selected private sector banks in India?

\subsection{RESEARCH OBJECTIVES:}

The broad objectives of the study are:

$>$ To study the NPA ratios of selected private sector banks from the viewpoint of ALM.

$>$ To compare the NPA ratios of private sector banks from the viewpoint of ALM and to analyze if they are exposed to similar credit risk.

$>$ To give findings and suggestions on the basis of the study.

\subsection{HYPOTHESIS:}

Ho: There is no significant difference in Credit Risk exposure (based on ratios) among selected private sector banks in India.

$\mathbf{H}_{1}$ : There is significant difference in Credit Risk exposure (based on ratios) among selected private sector banks in India.

3.4 RESEARCH DESIGN: The present study is descriptive in nature.

3.5 SAMPLING DESIGN: A sample of 5 new generation private sector banks is taken into consideration for the study. The sample banks are ICICI Bank, Axis Bank, HDFC Bank, Kotak Mahindra Bank and Yes Bank.

3.6 SOURCES OF DATA: The present study is based on secondary data collected from journals, books, Reserve Bank of India website, bank websites and moneycontrol.in.

3.7 PERIOD OF STUDY: The study covers a period of 8 years (2011-'12 to 2018-'19).

3.8 DATA ANALYSIS: The study analyzes the credit risk using NPA ratios and other ratios depicting credit risk of banks and statistical technique, One Way ANOVA is used to statistically prove or disprove the hypothesis.

\subsection{LIMITATIONS OF THE STUDY:}

$>$ The study is confined to selected private sector banks only for a specific period of 8 years only.

$>$ The study is completely based on secondary data collected from annual reports of banks.

$>$ Only selected ratios have been analyzed to study credit risk of banks. Ratios have their own limitations.

\section{RESULTS \& DISCUSSIONS}

\subsection{NPA RATIO:}

The NPA ratio is a measure to determine net NPAs to loans and advances. It measures the credit quality of lending's by banks. It is an important measure as it affects the net interest margin and net interest income of the bank. It also impacts the capital adequacy ratio.

Ho: There is no significant difference in Net NPAs of selected private sector banks.

Anova: Single Factor

Table 4.1

\begin{tabular}{|c|c|c|c|c|}
\hline Groups & Count & Sum & Average & Variance \\
\hline ICICI bank & 8 & 20.21 & 2.52625 & 3.8139411 \\
\hline
\end{tabular}




\begin{tabular}{|c|c|c|c|c|c|c|}
\hline \multirow{2}{*}{$\begin{array}{l}\text { GRAND ACADEMIC PORTAL } \\
\text { RESEARCH JOURNALS } \\
\text { Axis bank }\end{array}$} & \multicolumn{5}{|c|}{$\begin{array}{l}\text { A Global Journal of Interdisciplinary Studies } \\
\text { ( ISSN - 2581-5628 ) } \\
\text { Impact Factor: SJIF - 5.047, IIFS - } 4.875 \\
\text { Globally peer-reviewed and open access journal. }\end{array}$} & \\
\hline & 8 & 12.51 & 1.56375 & 2.1915982 & & \\
\hline HDFC bank & 8 & 2.24 & 0.28 & 0.0050857 & & \\
\hline Kotak Bank & 8 & 7.3 & 0.9125 & 0.0524786 & & \\
\hline Yes Bank & 8 & 3.84 & 0.48 & 0.3998 & & \\
\hline \multicolumn{7}{|l|}{ ANOVA } \\
\hline Source of Variation & SS & $\mathrm{df}$ & MS & $\mathrm{F}$ & P-value & F critical \\
\hline Between Groups & 26.619425 & 4 & 6.6548563 & 5.1485034 & 0.002276 & 2.641465 \\
\hline Within Groups & 45.240325 & 35 & 1.2925807 & & & \\
\hline Total & 71.85975 & 39 & & & & \\
\hline
\end{tabular}

4.2 NET NON-PERFORMING ASSETS TO TOTAL ASSETS (in \%):

This ratio indicates the efficiency of the bank in assessing credit risk and, to an extent, recovering the debts. The ratio is arrived by dividing the Net NPAs by Total Assets. Total assets considered are net of revaluation reserves. Lower ratio indicates better quality of advances (better utilization of assets) \& performance of the Bank.

Ho: There is no significant difference in Net NPAs to Total Assets ratio of selected private sector banks.

Anova: Single Factor

Table 4.2

\begin{tabular}{|c|c|c|c|c|c|c|}
\hline Groups & Count & Sum & Average & Variance & & \\
\hline ICICI bank & 8 & 12.3 & 1.5375 & 1.27539286 & & \\
\hline Axis bank & 8 & 7.81 & 0.97625 & 0.86456964 & & \\
\hline HDFC bank & 8 & 1.44 & 0.18 & 0.00314286 & & \\
\hline Kotak Bank & 8 & 4.54 & 0.5675 & 0.02285 & & \\
\hline Yes Bank & 8 & 2.377 & 0.297125 & 0.16369755 & & \\
\hline \multicolumn{7}{|l|}{ ANOVA } \\
\hline Source of Variation & SS & $\mathrm{df}$ & MS & $\mathrm{F}$ & P-value & F critical \\
\hline Between Groups & 9.818426 & 4 & 2.4546066 & 5.26818091 & 0.001984 & 2.641465 \\
\hline Within Groups & 16.30757 & 35 & 0.4659306 & & & \\
\hline Total & & 39 & & & & \\
\hline
\end{tabular}

The descriptive data shows that the average NPA to total assets of ICICI Bank tend to be higher than other banks.

The results of One-way Anova indicates that that the P-value is much lesser than level of significance - $5 \%$ and $\mathrm{F}$ value is also beyond the $\mathrm{F}$ critical region and hence we fail to accept null hypothesis and accept alternate hypothesis that there is significant difference in NPA to Total Assets ratio of selected private sector banks.

\subsection{CREDIT TO DEPOSIT RATIO (in \%):}

This ratio indicates how much of the advances lent by banks is done through deposits. It is the proportion of loan-assets created by banks from the deposits received. The higher the ratio, the higher the loan-assets created from deposits. The result of this ratio reflects the ability of the bank to make optimal use of the available resources.

Ho: There is no significant difference in Credit to Deposit ratio of selected private sector banks.

Anova: Single Factor

Table 4.3

\begin{tabular}{|c|c|c|c|c|c|c|}
\hline Groups & Count & Sum & Average & Variance & & \\
\hline ICICI bank & 8 & 786.92 & 98.365 & 36.0092286 & & \\
\hline Axis bank & 8 & 695.96 & 86.995 & 54.4799429 & & \\
\hline HDFC bank & 8 & 667.1 & 83.3875 & 9.84156429 & & \\
\hline Kotak Bank & 8 & 725.74 & 90.7175 & 27.1877929 & & \\
\hline Yes Bank & 8 & 693.31 & 86.66375 & 162.962055 & & \\
\hline \multicolumn{7}{|l|}{ ANOVA } \\
\hline Source of Variation & SS & $\mathrm{Df}$ & MS & $\mathrm{F}$ & $\begin{array}{l}\mathrm{P} \text {-value } \\
\end{array}$ & F critical \\
\hline Between Groups & 1051.012 & 4 & 262.7529 & 4.5227278 & 0.004744 & 2.641465 \\
\hline Within Groups & 2033.364 & 35 & 58.09612 & & & \\
\hline Total & 3084.376 & 39 & & & & \\
\hline
\end{tabular}

The descriptive data shows that the average Credit Deposit ratio of ICICI Bank tend to be higher than other banks. 
